\title{
Studies on the Variability and Combining Ability for Improved Growth and Yield of Local Eggplant Genotypes (Solanum melongena L.)
}

\author{
Ndueso AKPAN*, Peter OGBONNA, Vincent ONYIA, Emeka OKECHUKWU, \\ Agatha ATUGWU, Ima-obong DOMINIC
}

University of Nigeria,Nsukka,EnuguStateNigeria; akpandueso@yahoo.com ("correspondingauthor);ogbonnaptr@yahoo.com; vincent.onyia@unn.edu.ng; emeka.okechukwu@unn.edu.ng;Agatha.atugwu@unn.edu.ng;amicable4sure2004@yahoo.com

\begin{abstract}
Ten genotypes of eggplant (Solanum melongena L.) comprising of four genitors and six hybrids generated using diallel crosses were evaluated to estimate the magnitude of genetic variability, their general combing ability (GCA) and specific combining ability (SCA) for improved growth and yield of eggplant. The results obtained showed a significant $(\mathrm{p} \leq 0.05)$ difference among the genotypes in all the traits studied. The highest fruit yield per plant and fruit yield per hectare was obtained in 'Yalo' $\times$ 'K3' combination, with $1.77 \mathrm{~kg}$ per plant and 50.50 tonnes per hectare, respectively. The cluster analysis grouped the studied genotypes into three and six clusters for genitors alone and genitors with first filial generation $\left(\mathrm{F}_{1} \mathrm{~s}\right)$, respectively. Principal component analysis showed that number of leaves, number of fruits and number of branches per plant contributed more to the total variations observed in the eggplant populations. Significant GCA and SCA effect were obtained for most characters analyzed, indicating the importance of both additive and non-additive genetic components. The genotype 'Iyoyo' was the best general combiner in regard to days to flowering and number of fruits per plant. 'Yalo' was the best general combiner in fruits' circumference and diameter, fruit yield per plant and per hectare. The cross 'Uyo' $\times$ 'Iyoyo' was the best specific combiner in days to flowering, whereas 'K3' × 'Iyoyo' and 'Yalo' × 'K3' were the best specific combinations in number of fruits, fruit yield per plant and per hectare.
\end{abstract}

Keywords: hybrids, diallel analysis, mating design, genetic diversity, gene effect

\section{Introduction}

Eggplant (Solanum melongena L.) is a commercially and nutritionally important solanaceous vegetable crop grown extensively throughout the year in all parts of the world. It is widely cultivated in both subtropical and tropical regions of the globe mainly for its immature fruit and leaves used as vegetables. It is popular among people of all social strata and hence, it is referred as "vegetable of the masses" (Roychowdhury and Tah, 2011). In the face of increasing population, there is a need for increased production and productivity levels of eggplant. In view of very high local preferences for traits such as size, colour, shape, taste, there are specific genotypes suited for specific locality. It is not possible to have one common cultivar to suit different areas and local preferences. It is therefore important to improve the yield potential of eggplants through hybridization, as this will yield good hybrids or hybrid derivatives (Sherly, 2007). In Nigeria, productivity of eggplant is low as compared to the other eggplant growing countries; this could be due to the use of low yielding cultivars grown for local preferences (Nalini, 2007).
In breeding for high yielding crop plants through hybridization, the breeders are often faced with the problem of selecting genitors and crosses. The performance of genotypes is not always a good index of their superior combining ability. Certain cross combinations nick well to provide superior hybrids where as others involving equally promising genitors produce disappointing progeny (Reddy et al., 2013). Hence, there is a constant need to screen germplasm to isolate potential combining lines and desirable cross combinations, either to exploit heterosis or to obtain new recombinants. Thus, any method which would help in choosing desirable genitors and crosses will be important for breeders. Genetic analysis provides a guideline for the assessment of relative breeding potential of the genitors or identifies best combiners (Devi et al., 2005).

Diallel analysis of self and cross pollinated populations is used to study the genetic control of quantitative traits (Hayman, 1958) and to assess general and specific combining abilities (Griffing, 1956). Diallel mating design has been used extensively by several researchers to measure general and specific combining ability in eggplant. 
The present investigation was undertaken to elucidate information on combining ability of several eggplant genotypes in order to obtain superior hybrids, of excellent high yields, and in addition, to identify hybrid combinations valuable for commercial exploitation.

\section{Materials and Methods}

The experiment was conducted at the Teaching and Research Field of the Department of Crop Science, University of Nigeria, Nsukka, Nigeria (latitude 60511E and longitude $70291 \mathrm{~N}, 475 \mathrm{~m}$ above sea level); the area is characterized by lowland humid condition with bimodal annual rainfall distribution that ranges from $1,155 \mathrm{~mm}$ to $1,955 \mathrm{~mm}$, a mean annual temperature of $29^{\circ} \mathrm{C}$ to $31^{\circ} \mathrm{C}$ and relative humidity that ranges from 69 to $79 \%$ (Uguru et al., 2011).

Four superior and optimally divergent genotypes namely: 'Yalo', 'Uyo', 'K3' and 'Iyoyo' were crossed in all possible combinations excluding reciprocals to generate six (6) single crosses during 2014 (April-July) planting season.

Six half diallel progenies along with their four parental lines were evaluated in a randomized complete block design (RCBD) with three replicates from April-July, 2015. Each block had ten plots measuring $2.8 \times 3 \mathrm{~m}^{2}$. Planting was done at a spacing of $70 \mathrm{~cm} \times 50 \mathrm{~cm}$. Each plot had twenty four plants per genotype. Inorganic compound fertilizer (NPK 20:10:10) was applied at the rate of $300 \mathrm{~kg}$ per hectare at two weeks after transplanting. Weeding was done manually on the field as when due.

The data collected comprised: plant height $(\mathrm{cm})$, number of leaves, number of branches, stem girth $(\mathrm{cm})$, days to $50 \%$ and $100 \%$ flowering, number of fruits per plant, fruit yield per plant $(\mathrm{kg})$, fruit yield per hectare (tonnes), fruit circumference $(\mathrm{cm})$ and diameter $(\mathrm{cm})$.

The variations among the hybrids obtained within the experiment were partitioned into genetic components attributable to general combining ability (GCA) and specific combining ability (SCA) following the Griffings (1956) model 1, method 2 (genitors, $F_{1} s$ without reciprocal) as explained by Singh and Chaudhary (1985). The data obtained were subjected to the following analysis: analysis of variance (ANOVA) following randomized complete block design (RCBD) procedures, principal component analysis (PCA) and cluster analysis using GenStat Release 10.3 Discovery Edition 4 software (GenStat, 2011).

\section{Results}

The evaluation results of the genitors and hybrids presented in Table 1 showed that there was a significant ( $\mathrm{p}$ $\leq 0.05$ ) difference among the genitors and hybrids of eggplant for all the traits measured. The results showed that the hybrids were significantly improved than their genitors in respect to plant height; 'K3' × 'Iyoyo' (84.55 $\mathrm{cm}$ ) produced the tallest plants, while the least height was obtained for 'Yalo' genotype $(70.33 \mathrm{~cm})$. Significantly, 'Yalo' had the biggest fruit circumference $(24.05 \mathrm{~cm})$ and diameter $(11.83 \mathrm{~cm})$, while the least was obtained in 'Iyoyo' (7.03 and $2.98 \mathrm{~cm}$, respectively). The highest number of fruits per plant was obtained in 'K3' $\times$ 'Iyoyo' (109.10) and the least was observed in 'Yalo' (11.30). The highest fruit yield per plant and fruit yield per hectare was obtained in 'Yalo' $\times$ 'K3' (1.77 kg per plant and 50.50 tonnes per hectare) and the least in 'Iyoyo' $(0.40 \mathrm{~kg}$ per plant and 11.40 tonnes per hectare), respectively.

The principal component analysis revealed that the first and second principal components accounted for $96.29 \%$ and $3.59 \%$, respectively, for the total variation observed among the genitor genotypes alone (Table 2). For the genitors and $\mathrm{F}_{1}$ hybrids, first and second principal components accounted for $91.64 \%$ and $5.47 \%$, respectively, for the total variation observed among the eggplant genotypes. The Latent vectors revealed that in principal component 1 , the number of leaves per plant contributed with the highest load of 0.84002 , followed by the number of fruits per plant and the number of branches per plant, with contributing loads of 0.44274 and 0.23046 , respectively, for the variation among the genitor genotypes. Similarly, the principal component 1 for the genitors and $F_{1}$ genotypes combined showed that the number of leaves per plant contributed with the highest load of 0.77833 , followed by the number of fruits per plant and the number of branches per plant with contributing loads of 0.57593 and 0.20676 , respectively.

The cluster analysis grouped the genitors' genotypes of eggplant into three clusters (A, B and C) based on the diversity of the studied traits using a scale of 0.9 as the similarity axis (Fig. 1). Cluster A had 'Yalo', cluster B consisted of 'Uyo' and 'K3', while cluster C had 'Iyoyo' genotype. Cluster analysis on Fig. 2 grouped the hybrids generated and their genitors into six clusters (A to F), as

Table 1. Mean performance on the agronomic traits of the genitors and $F_{1}$ eggplant genotypes

\begin{tabular}{|c|c|c|c|c|c|c|c|c|c|c|c|}
\hline Genotypes & $\mathrm{PH}$ & $\mathrm{NB}$ & $\mathrm{NL}$ & SG & $\mathrm{D} 50 \mathrm{~F}$ & D100F & FC & FD & $\mathrm{NF}$ & $\mathrm{FY} / \mathrm{P}$ & $\mathrm{FY} / \mathrm{H}$ \\
\hline \multicolumn{12}{|l|}{ Genitors } \\
\hline 'Yalo' & 70.33 & 18.72 & 94.30 & 4.02 & 26.00 & 32.33 & 24.05 & 11.83 & 11.30 & 1.64 & 46.90 \\
\hline 'Uyo' & 73.50 & 15.94 & 94.40 & 4.25 & 24.67 & 33.33 & 14.03 & 6.67 & 26.80 & 0.84 & 24.10 \\
\hline 'K3' & 75.89 & 14.78 & 77.60 & 4.57 & 23.33 & 34.00 & 17.73 & 8.92 & 19.60 & 1.06 & 30.40 \\
\hline 'Туоуо' & 70.67 & 46.72 & 197.70 & 2.84 & 19.00 & 29.33 & 7.03 & 2.98 & 76.60 & 0.4 & 11.40 \\
\hline \multicolumn{12}{|l|}{ Hybrids } \\
\hline 'Yalo' × 'Uyo' & 83.78 & 23.15 & 107.00 & 4.33 & 23.67 & 30.67 & 18.72 & 8.98 & 31.70 & 1.33 & 38.10 \\
\hline 'Yalo'× ‘K3' & 77.45 & 19.22 & 99.70 & 5.28 & 20.67 & 29.33 & 19.26 & 9.15 & 40.00 & 1.77 & 50.50 \\
\hline 'Yalo' × 'Iyoyo' & 80.28 & 42.22 & 183.00 & 3.90 & 22.00 & 28.67 & 11.09 & 5.33 & 88.90 & 1.24 & 34.40 \\
\hline 'Uyo' × 'K3' & 81.39 & 19.38 & 108.90 & 5.02 & 23.33 & 32.00 & 16.90 & 8.27 & 27.70 & 1.15 & 32.80 \\
\hline 'Uyo' × 'Iyoyo' & 77.00 & 32.00 & 157.70 & 3.56 & 19.33 & 28.67 & 9.66 & 4.56 & 69.20 & 0.80 & 23.00 \\
\hline 'K3' × 'Іуоуо' & 84.55 & 38.00 & 171.10 & 3.94 & 25.67 & 31.67 & 10.93 & 5.07 & 109.10 & 1.19 & 33.90 \\
\hline $\operatorname{LSD}_{(0.05)}$ & 7.04 & 8.40 & 52.10 & 0.43 & 3.43 & 3.00 & 1.38 & 0.98 & 22.97 & 0.37 & 10.63 \\
\hline
\end{tabular}


228

Table 2. Principal component analysis (PCA) on the agronomic traits of eggplant genitors and genitor $/ \mathrm{F}_{1}$ genotypes

\begin{tabular}{lcccc}
\hline \multirow{2}{*}{ rait } & \multicolumn{2}{c}{ Genitors genotype alone } & \multicolumn{2}{c}{ Genitor and $\mathrm{F}_{1}$ genotypes } \\
\cline { 2 - 5 } & Vector 1 & Vector 2 & Vector 1 & Vector 2 \\
\hline D100F & -0.02995 & 0.05168 & -0.02317 & -0.00273 \\
D50F & -0.04228 & -0.06666 & -0.01896 & -0.07330 \\
FC & -0.09157 & -0.30284 & -0.08121 & -0.10290 \\
FD & -0.04892 & -0.15012 & -0.04285 & -0.04920 \\
\hline FY_H & -0.17656 & -0.72620 & -0.10014 & -0.56687 \\
FY_P & -0.00616 & -0.02554 & -0.00341 & -0.02006 \\
NB & $\mathbf{0 . 2 3 0 4 6}$ & -0.14907 & $\mathbf{0 . 2 0 6 7 6}$ & 0.10301 \\
NF & $\mathbf{0 . 4 4 2 7 4}$ & 0.40983 & $\mathbf{0 . 5 7 5 9 3}$ & -0.66408 \\
NL & $\mathbf{0 . 8 4 0 0 2}$ & -0.36703 & $\mathbf{0 . 7 7 8 3 3}$ & 0.38110 \\
PH & -0.0209 & 0.15969 & 0.01783 & -0.24961 \\
SG & -0.01115 & 0.01509 & -0.00882 & -0.02672 \\
Percent & 96.29 & 3.59 & 91.64 & 5.47 \\
variation & 9 & & & \\
\hline D50F $=$ days to & $50 \%$ flowering & & \\
\hline
\end{tabular}

circumference $(\mathrm{cm}), \mathrm{FD}=$ fruit diameter $(\mathrm{cm}), \mathrm{NB}=$ number of branches per plant, $\mathrm{NF}=$ number of fruits per plant, $\mathrm{NL}=$ number leaves per plant, $\mathrm{PH}=$ plant height $(\mathrm{cm}), \mathrm{SG}=$ stem girth $(\mathrm{cm}), \mathrm{FY} / \mathrm{P}=$ fruits per plant $(\mathrm{kg}), \mathrm{FY} / \mathrm{H}=$ fruits yield per hectare (tonnes/hectare).

follows: cluster A had 'Yalo', cluster B consisted of 'Uyo' and ' $\mathrm{K} 3$ ', cluster $\mathrm{C}$ comprised of 'Yalo' $\times$ ' $U y o$ ' $F_{1}$, 'Uyo' $\times$ 'K3' $\mathrm{F}_{1}$ and 'Yalo' $\times$ ' $\mathrm{K} 3$ ' $\mathrm{F}_{1}$, cluster D had 'Iyoyo', cluster $\mathrm{E}$ made up of 'Yalo' $\times$ 'Iyoyo' $F_{1}$ and 'Uyo' $\times$ 'Iyoyo' $F_{1}$ and cluster F had 'K3' × 'Iyoyo' $F_{1}$.

Analysis of variance for the combining ability on the agronomic traits of eggplant presented in Table 3 showed a significant GCA effect in all the attributes except of plant height. Significant SCA effect was obtained in all the traits measured with exception of the number of branches per plant, number of leaves per plant, fruit yield per plant and fruit yield per hectare. The GCA/SCA ratio, which indicates the relative importance of additive gene effect, showed a GCA/SCA ratio greater than one in all the traits except in plant height (0.003), days to $50 \%$ flowering $(0.15)$, days to $100 \%$ flowering $(0.41)$ and number of fruit per plant $(0.69)$.

Table 4 show the GCA estimate for agronomic traits of eggplant genotypes used as genitors. The results indicated that 'Yalo' genotype had a significant high GCA in fruit circumference (3.75), fruit diameter (1.87), fruit yield per plant (0.32) and fruit yield per hectare (9.01). All others traits showed a non-significant low GCA effect except the number of fruits per plant $(-11.21)$ which showed a significant low GCA effect. 'Uyo' genotype showed a significant low GCA effect in the number of fruits per plant (-11.38), fruit yield per plant $(-0.13)$ and fruit yield per hectare (-3.44). Non-significant high GCA effect was obtained in plant height (0.29), stem girth $(0.09)$, days to $50 \%(0.31)$ and $100 \%(0.50)$ flowering.

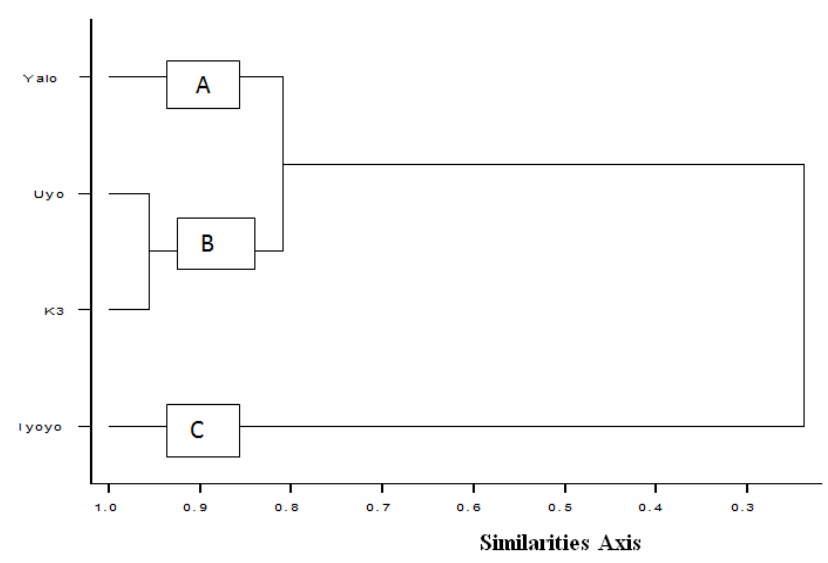

Fig. 1. Dendrogram showing the classification of 4 genitor eggplant genotypes

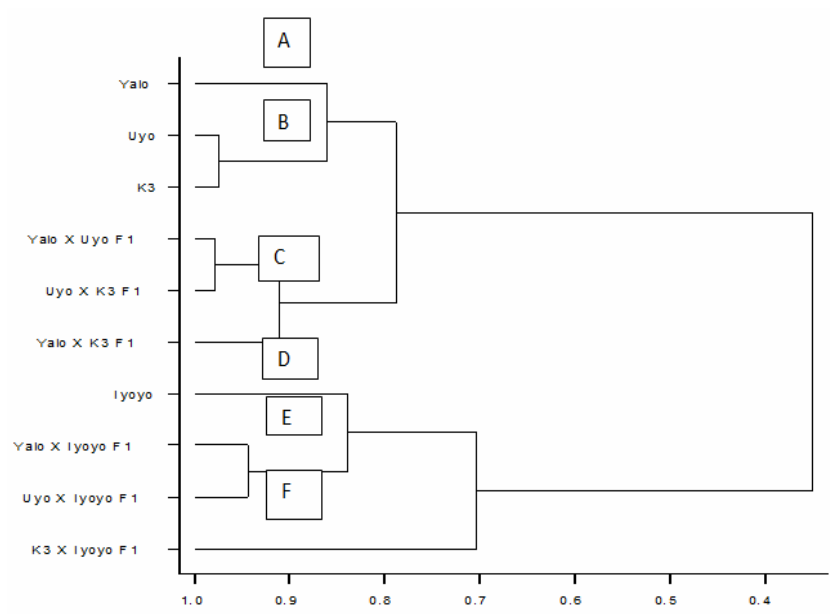

Fig. 2. Dendrogram showing the classification of 10 eggplant genotypes (genitors $/ \mathrm{F}_{1}$ )

The genotype ' $\mathrm{K} 3$ ' had a non-significant high GCA effect in most of the traits such as fruit yield per plant (0.09) and fruit yield per hectare (2.54). 'K3' showed a significant low GCA effect in number of branches per plant $(-4.82)$, number of leaves per plant (-18.47) and a non-significant low GCA effect in number of fruits per plant $(-5.75)$. 'Iyoyo' had a significant low GCA effect in all the traits with exception of the number branches per plant (11.77), number of leaves per plant (43.58) and number of fruits per plant (28.32) that had a significantly high GCA effect.

The results presented in Table 5 show that the specific combining ability (SCA) effects of the crosses. 'Yalo' $\times$ 'Uyo' had a significant SCA effect in plant height (6.88) and a non-significant high SCA effect in number of

Table 3. Analysis of variance for combining ability on the agronomic traits of genitors and $\mathrm{F}_{1}$ hybrid of eggplant genotypes

\begin{tabular}{lcccccccccccc}
\hline & \multicolumn{10}{c}{ Mean square } \\
\hline SOV & d.f. & PH & NB & NL & SG & D 50F & D100F & FC & FD & NF & FY/P & FY/H \\
\hline GCA & 3 & $1.04^{\text {ns }}$ & $378.34^{* *}$ & $5118.92^{* *}$ & $1.18^{* *}$ & $5.60^{*}$ & $5.56^{* *}$ & $78.17^{* *}$ & $20.58^{* *}$ & $2180.58^{* *}$ & $0.41^{* *}$ & $330.40^{* *}$ \\
SCA & 6 & $35.13^{* *}$ & $17.52^{\text {ns }}$ & $277.43^{\text {ns }}$ & $0.14^{* *}$ & $6.16^{* *}$ & $2.88^{*}$ & $2.54^{* *}$ & $0.64^{* *}$ & $572.11^{* *}$ & $0.01^{\text {ns }}$ & $31.26^{\text {ns }}$ \\
Error & 18 & 5.61 & 8.00 & 307.48 & 0.02 & 1.33 & 1.02 & 0.21 & 0.11 & 59.75 & 0.02 & 12.80 \\
$\begin{array}{l}\text { GCA } / \text { SCA } \\
\text { Ratio }\end{array}$ & 0.003 & 6.48 & -26.69 & 1.58 & 0.15 & 0.41 & 5.58 & 6.43 & 0.69 & -6.50 & 2.87 \\
\hline
\end{tabular}

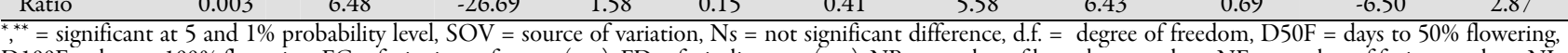
$\mathrm{D} 100 \mathrm{~F}=$ days to $100 \%$ flowering, $\mathrm{FC}=$ fruit circumference $(\mathrm{cm}), \mathrm{FD}=$ fruit diameter $(\mathrm{cm}), \mathrm{NB}=$ number of branches per plant, $\mathrm{NF}=$ number of fruits per plant, $\mathrm{NL}$ $=$ number leaves per plant, $\mathrm{PH}=$ plant height $(\mathrm{cm}), \mathrm{SG}=$ stem girth $(\mathrm{cm}), \mathrm{FY} / \mathrm{P}=$ fruits per plant $(\mathrm{kg}), \mathrm{FY} / \mathrm{H}=$ fruits yield per hectare (tonnes/hectare). 
Table 4. General combining ability estimate on the agronomic traits of genitors eggplant genotypes

\begin{tabular}{lccccccccccc}
\hline Genotypes & PH & NB & NL & SG & D50F & D100F & FC & FD & NF & FY/P & FY/H \\
\hline 'Yalo' & -0.88 & -2.17 & -11.23 & 0.11 & 0.75 & -0.28 & 3.75 & 1.87 & -11.21 & 0.32 & 9.01 \\
'Uyo' & 0.29 & -4.78 & -13.88 & 0.09 & 0.31 & 0.50 & -0.23 & -0.12 & -11.38 & -0.13 & -3.44 \\
'K3' & 1.29 & -4.82 & -18.47 & 0.42 & 0.42 & 1.00 & 1.31 & 0.74 & -5.75 & 0.09 & 2.54 \\
'Iyoyo' & -0.71 & 11.77 & 43.58 & -0.63 & -1.47 & -1.22 & -4.83 & -2.49 & 28.32 & -0.28 & -8.11 \\
S.E & 1.37 & 1.63 & 10.12 & 0.08 & 0.66 & 0.58 & 2.01 & 0.19 & 4.46 & 0.08 & 2.07 \\
C.D $(0.05)$ & 2.65 & 2.45 & 15.20 & 0.12 & 1.00 & 0.88 & 3.02 & 0.29 & 6.70 & 0.12 & 3.10 \\
\hline
\end{tabular}

$\mathrm{D} 50 \mathrm{~F}=$ days to $50 \%$ flowering, D100F = days to $100 \%$ flowering, $\mathrm{FC}=$ fruit circumference $(\mathrm{cm}), \mathrm{FD}=$ fruit diameter $(\mathrm{cm}), \mathrm{NB}=$ number of branches per plant, $\mathrm{NF}=$ number of fruits per plant, $\mathrm{NL}=$ number leaves per plant, $\mathrm{PH}=$ plant height $(\mathrm{cm}), \mathrm{SG}=$ stem girth $(\mathrm{cm}), \mathrm{FY} / \mathrm{P}=$ fruits per plant $(\mathrm{kg}), \mathrm{FY} / \mathrm{H}=$ fruits yield per hectare (tonnes/hectare).S.E = standard error, C.D = Critical differences

Table 5. Specific combining ability estimate on the agronomic traits of hybrid eggplant genotypes

\begin{tabular}{|c|c|c|c|c|c|c|c|c|c|c|c|}
\hline Crosses & $\mathrm{PH}$ & $\mathrm{NB}$ & NL & SG & D5F & $\mathrm{D} 100 \mathrm{~F}$ & $\mathrm{FC}$ & FD & NF & $\mathrm{FY} / \mathrm{P}$ & $\mathrm{FY} / \mathrm{H}$ \\
\hline 'Yalo' × 'Uyo' & 6.88 & 3.09 & 2.97 & -0.05 & -0.15 & -0.55 & 0.26 & 0.05 & 4.19 & -0.01 & -0.02 \\
\hline 'Yalo' × 'K3' & -0.45 & -0.80 & 0.26 & 0.57 & -3.26 & -2.39 & -0.73 & -0.64 & 6.86 & 0.22 & 6.40 \\
\hline 'Yalo' × 'Iyoyo' & 4.38 & 5.62 & 21.51 & 0.24 & -0.04 & -0.83 & -2.77 & -1.23 & 21.69 & 0.06 & 0.95 \\
\hline 'Uyo' × 'K3' & 2.33 & 1.96 & 12.11 & 0.33 & -0.16 & -0.50 & 0.88 & 0.47 & -5.28 & 0.05 & 1.15 \\
\hline 'Uyo' × 'Iyoyo' & 0.10 & -2.00 & -1.14 & -0.06 & -2.28 & -1.61 & -0.23 & -0.01 & 2.16 & 0.06 & 2.00 \\
\hline 'K3' × 'Iyoyo' & 6.49 & 4.04 & 16.84 & -0.03 & 3.96 & 0.89 & -0.49 & -0.36 & 36.42 & 0.24 & 6.92 \\
\hline S.E & 2.03 & 2.42 & 15.02 & 0.12 & 0.99 & 0.86 & 0.39 & 0.28 & 6.62 & 0.12 & 3.06 \\
\hline C.D $(0.05)$ & 4.11 & 4.90 & 30.41 & 0.23 & 2.00 & 1.75 & 0.79 & 0.58 & 13.4 & 0.25 & 6.20 \\
\hline
\end{tabular}
$\mathrm{NF}=$ Number of fruits per plant, $\mathrm{NL}=$ Number leaves per plant, $\mathrm{PH}=$ Plant height $(\mathrm{cm}), \mathrm{SG}=\mathrm{Stem}$ girth $(\mathrm{cm}), \mathrm{FY} / \mathrm{P}=\mathrm{Fruits}$ per plant $(\mathrm{kg}), \mathrm{FY} / \mathrm{H}=\mathrm{Fruits}$ yield per hectare (tone $/$ ha), $S . E=$ Standard error, C.D = Critical differences

branches per plant (3.09), number of leaves per plant (2.97), fruits' circumference (0.26), fruits' diameter $(0.05)$ and number of fruits per plant (4.19). A non-significant low SCA effect in stem girth (-0.05), days to $50 \%(-0.15)$ and $100 \%(-0.55)$ flowering, fruit yield per plant $(-0.01)$ and fruit yield per hectare $(-0.02)$ was as well obtained.

The hybrid combination 'Yalo' $\times$ 'K3' showed a significant high SCA effect in stem girth (0.57) and fruit yield per hectare (6.40) and non-significant high SCA effect in number of leaves per plant (0.26), number of fruits per plant (6.86) and fruit yield per plant (0.22). Significant low SCA effect was obtained in days to 50\% ($3.26)$ and $100 \%(-2.39)$ flowering and fruits' diameter ($0.64)$ and a non-significant low SCA effect in plant height $(-0.45)$, number of branches per plant $(-0.80)$ and fruits' circumference $(-0.76)$. The hybrid combination 'Yalo' $x$ 'Iyoyo' had a significant high SCA effect in plant height (4.38), number of branches per plant (5.62), stem girth (0.24) and number of fruits per plant (21.69) and a nonsignificant high SCA effect in number of leaves per plant (21.51), fruit yield per plant (0.06) and fruit yield per hectare (0.95). Significant a low SCA effect was obtained in fruits' circumference (-2.77) and fruits' diameter $(-1.23)$ and non-significant low SCA effect in days to 50\% (-0.04) and $100 \%(-0.83)$ flowering.

The hybrid combination 'Uyo' $\times$ 'K3' showed a significant high SCA effects in stem girth (0.33) and fruits' circumference $(0.88)$ and a non-significant high SCA effect in plant height (2.33), number of branches per plant (1.96), number of leaves per plant (12.11), fruits' diameter $(0.47)$, fruit yield per plant $(0.05)$ and fruit yield per hectare (1.15). Days to $50 \%(-0.16)$ and $100 \%(-0.50)$ flowering and number of fruits per plant $(-5.28)$ showed a non-significant low SCA effect. 'Uyo' $\times$ 'Iyoyo' showed a non-significant high SCA effect in plant height $(0.10)$, number of fruits per plant (2.16), fruit yield per plant $(0.06)$ and fruit yield per hectare (2.00). A significant low SCA effect was obtained in days to $50 \%$ flowering $(-2.28)$ and a non-significant low SCA effect in number of branches per plant $(-2.00)$, number of leaves per plant ($1.14)$, stem girth (-0.06), days to $100 \%$ flowering $(-1.61)$, fruits' circumference $(-0.23)$ and fruits' diameter $(-0.01)$. The hybrid combination 'K3' × 'Iyoyo' had a significant high SCA effect in plant height (6.49), days to 50\% flowering (3.96), number of fruits per plant (36.42), fruit yield per hectare (6.92) and non-significant high SCA effect in number of branches (4.04), number of leaves per plant (16.84), days to $100 \%$ flowering (0.89) and fruit yield per plant (0.24). A non-significant low SCA effect was obtained in stem girth (-0.03), fruits' circumference ($0.49)$ and fruits' diameter $(-0.36)$.

\section{Discussion}

Estimation of variability is an important prerequisite for estimating the response to selection as the progress in breeding depends upon its amount, nature and magnitude (Kumar $e t a l$., 2013). The significant $(p \leq 0.05)$ differences observed among the genotypes for all the traits suggested the existence of inherent genetic variability among the studied genotypes. This result is also in line with data of Rajib et al. (2011) and Kumar et al. (2013) who have earlier reported the existence of genetic variation among eggplant genotypes. The result of principal component analysis of the present study corroborated with the findings of Uddin et al. (2014) who found that the number of branches per plant and the number of fruit per plant contributed to the highest variation among eggplant genotypes; the authors further noted that fruit weight, fruit length and days to $50 \%$ flowering were also important to some extent for the variation observed.

Genetic assessment of germplasm is commonly undertaken by plant breeders to understand genetic variation in the germplasm and to discover patterns of genetic diversity. Analysis of genetic diversity levels in germplasm helps plant breeders to make proper choices of genitors of use in breeding programs (Acquaah, 2007). The result of cluster analysis 
230

grouped the genotypes of eggplant into three and six clusters for the genitors only and hybrids and their genitors, respectively, which indicated sufficient genotypic variation among the eggplant genotypes that can be exploited for further improvement programs. This is in accordance with Kumar et al. (2008) and Nyadanu et al. (2014) who revealed wide diversity in eggplant.

Combining ability is used to evaluate the performance of a selected line in combination with others. General and specific combining abilities are important indicators of the potential of parental lines for generating superior breeding populations (Idahosa and Alika, 2013). The highly significant effect of both GCA and SCA effect for attributes measured indicated the importance of both additive and non-additive gene action for the traits measured. This result is in agreement with the findings of Al-Hubaity and Teli (2013), Patel et al. (2013) who observed a highly significant GCA and SCA effects in eggplant. The GCA/SCA variance ratio higher than one in some attributes suggests the importance of additive gene effect in all the traits measured except in plant height, number of fruits per plant, days to $50 \%$ and $100 \%$ flowering. These data are agreement with those of Patel $e t$ al. (2013) who observed a GCA/SCA ratio less than one in plant height, number of fruits per plant and days to $50 \%$ flowering. A small or negative combining effect indicates a poor ability to transfer genetic superiority to hybrids. The largest positive values have the largest effects. On the other hand, the largest negative values have the smallest effects. A high positive GCA value means that the parental lines have high potential for generating superior offspring.

The genitor 'Iyoyo' was a good general combiner in several attributes such as number of branches per plant, number of leaves per plant and number of fruits per plant. Negative values for days to $50 \%$ and $100 \%$ flowering are desirable (Patel et al., 2013). As such, 'Iyoyo' was a good a general combiner for days to $50 \%$ and $100 \%$ flowering. 'Yalo' was a good general combiner in fruits' circumference and diameter; fruit yield per plant and fruit per hectare, whereas ' $\mathrm{K} 3$ ' was a good general combiner for plant height and stem girth.

The GCA effect together with relative performance is useful for selecting desirable genitors with favorable genes for different components traits of yield. The performance of the genitors and their GCA effects for all the studied traits were in close agreement, indicating that the performance of the genitors for these traits could possibly be taken as criteria for selection. GCA effects represent additive interaction effects. In eggplant, the importance of this type of interaction had been reported by many researchers like Suneetha et al. (2006), Sao and Mehta, (2010), Patel et al. (2013).

In general, SCA is associated with interaction effect which may be due to dominance and epistatic components of variation that is non-fixable in nature. Hence, it can be used in $F_{1}$ generation only for the development of hybrid varieties (Patel et al., 2013). 'K3' × 'Iyoyo' was a good specific combiner for number fruits per plant, fruit yield per plant and fruit yield per hectare. 'Uyo' $\times$ ' $\mathrm{K} 3$ ' was a good specific combiner for fruit circumference and diameter. This agreed with the findings of Sao and Mehta
(2010), Al-Hubaity and Teli (2013), Patel et al., (2013) who observed similar results in their research in eggplant.

\section{Conclusions}

There was a significant difference within the growth and yield performance among the eggplant genotypes used, suggesting the existence of inherent genetic variability among the genotypes, which is important for successful selection and yield breeding programs. General combining ability estimate identified 'Yalo', 'K3' and 'Iyoyo' genotypes as the suitable general combiner in regard with fruits' circumference, fruit diameter, number of fruits per plant, days to flowering, fruit yield per plant and fruit yield per hectare, meaning that these genotypes had the ability to transfer their genetic superiority to their offspring. The crosses 'K3' $\times$ 'Iyoyo', 'Yalo' $\times$ 'K3' and 'Uyo' $\times$ 'Iyoyo' were identify as the best specific combiner in number of fruits per plant, days to flowering, fruit yield per plant and fruit yield per hectare.

\section{References}

Acquaah G (2007). Principles of plant genetics and breeding. Blackwell Publishing, Oxford.

Al-Hubaity AI, Teli JA (2013). Combining ability and heterosis in eggplant (Solanum melongena L.). Mesopotamia Journal of Agriculture 41(1):23-35.

Devi ES, Singh NB, Devi AB, Singh NG, Laishram GM (2005). Gene action for fruit yield and its components in tomato (Lycopersicon esculentum Mill.) Indian Journal of Genetics and Plant Breeding 65:221-222.

Griffing B (1956). Concept of general and specific combining ability in relation to diallel crossing systems. Australian Journal of Biologcal Science 9:463-493.

GenStat (2011). GenStat Release 10.3DE (PC/Windows 7).

Hayman BI (1958). The separation of epistatic from additive and dominance variation in generation means. Heredity 12:371-390.

Idahosa DO, Alika JE (2013). Diallel analysis of six agronomic characters in Vigna unguiculata genotypes. African Journal of Plant Breeding 1:001-007.

Kumar G, Meena BL, Kar R, Gangopadhyay KK, Bisht IS, Mahajan RK (2008). Morphological diversity in brinjal (Solanum melongena L.) germplasm accessions. NIAB Plant Genetic Resources: Characterization and Utilizations 6:232-236.

Kumar SR, Arumugam T, Anandakumar CR, Premalakshmi V (2013). Genetic variability for quantitative and qualitative characters in Brinjal (Solanum melongena L.). African Journal of Agricultural Research 8(39):4956-4959.

Nalini ID (2007). Studies on heterosis and combining ability in eggplant (Solanum melongena L.). MSc Thesis, University of Agricultural Sciences, Dharwad.

Nyadanu D, Aboagye LM, Akromah R, Osei MK, Dordoe MB (2014). Agromorphological characterization of gboma eggplant, an indigenous fruit and leafy vegetable in Ghana. African Crop Science Journal 22(4):281-289. 
Patel JP, Singh U, Kashyap SP, Singh DK, Goswami A, Tiwari SK, Singh M (2013). Combining ability for yield and other quantitative traits in eggplant (Solanum melongena L.) Vegetable Science 40(1):61-64.

Rajib R, Souri R, Jagatpati T (2011). Estimation of heritable components of variation and character selection in eggplant (Solanum melongena L.) for mutation breeding programme. Continental Journal Biological Sciences 4(2):31-36.

Reddy MT, Babu KH, Ganesh M, Begum H, Dilipbabu J, Reddy RSK (2013). Gene action and combining ability of yield and its components for late kharif season in okra (Abelmoschus esculentus

(L.) Moench). Chilean Journal Agricultural Research 73(1):9-15.

Roychowdhury R, Tah J (2011). Differential response by different parts of Solanum melongena L. for heavy metal accumulation. Plant Sciences Feed 1(6):80-83.

Sao A, Mehta N (2010). Heterosis in relation to combining ability for yield and quality attributes in Brinjal (Solanum melongena L.). Electronic Journal of Plant Breeding 1(4):783-788.
Singh K, Chaudhary BD (1985). Biometrical methods in quantitative genetic analysis. Kalyani Publishers. New Delhi-Ludhiana (India) pp 39-78.

Sherly J (2007). Evaluation of local types of eggplant (Solanum melongena L.). MSc Thesis, Pandit Jawaharlal Nehru College of Agriculture and Research Institute, Karaikal.

Suneetha Y, Kathiria KB, Srinivas T (2006). Diallel analysis for yield and yield components in summer brinjal (Solanum melongena $\mathrm{L}$.). International Journal Agricultural Science 2(2):411-413.

Uddin MS, Rahman MM, Hossain MM, Mian MAK (2014). Genetic diversity in eggplant genotypes for heat tolerance. SAARC Journal of Agriculture 12(2):25-39.

Uguru MI, Baiyeri KP, Abba SC (2011). Indicators of climate change in the derived savannah niche on Nsukka, South-Eastern Nigeria. Agriculture Science Journal of Tropical Agriculture, Food, Environment and Extension 10(1):1-10. 